\title{
Influence of Achieved Status on Clean and Healthy Behavior in Coastal Sasak West Pasaman
}

\author{
Widya Prarikeslan and Sri Mariya \\ Geography Department, Universitas Negeri Padang, Indonesia \\ Email: sri_riya305@yahoo.com
}

\begin{abstract}
This research is a survey research with explanatory research, data related to the achieved status and behavior of clean and healthy living is taken directly in the field. The method used in this research is correlational method, which consists of two variables are variable X (status achieved) and variable Y PHBS. Data analysis technique used multiple linear regression test at $95 \%$ confidence level. Data processing using SPSS to know the relationship between the status achieved with the clean and healthy behavior. Tool of data collection used in this research is a questionnaire. Implementation of this activity is planned for 1 phase done in 2016 with analyze, the relationship between the status achieved with the clean and healthy behavior.
\end{abstract}

Keywords: Coastal, Achieved Status, Behavior

\section{Introduction}

Cleanliness is one of the important factors that encourage the activity and creativity of individuals to achieve welfare impact on all levels of society. There are many things that can be the connecting factor. Suppose that cleanliness we hooked with health problems, there will be a strong reaction between the two. If we live cleanly then surely we will live healthy and vice versa. If we do not do a clean lifestyle then it will directly affect our health.

Depkes RI 2009 stated the behavior of clean and healthy life in the household is one of the implementation in realizing the human rights that deserved and championed by all parties. Therefore mobilizing and empowering families to live healthy and clean is the responsibility of regency / city government can be tried in related sectors of non-governmental organizations, community organizations, private and business to realize PHBS households.

Understanding PHBS Clean and Healthy Behavior (PHBS) is a set of behaviors practiced on the basis of awareness as a result of learning, which makes a person's family, group or community able to help himself (self) in health and play an active role in realizing public health. Thus, PHBS includes hundreds and perhaps even thousands of behaviors that must be practiced in order to achieve the highest degree of public health. In the field of disease prevention and prevention and environmental sanitation, practitioners should practice handwashing with soap, drinking water management and eligible foods, using clean water, healthy latrines, eligible liquid waste management, eradicating mosquito larvae, non-smoking indoors and etc. In the field of maternal and child health and family planning should be practiced the behavior of requesting the birth pennies by health workers, weighing children every month, immunizing complete infants, becoming family acceptor (MENKES, 2011).

Increased clean and healthy living behavior in the domestic order, the arrangement of educational institutions, the workplace order, the setting of public places and the arrangement of health facilities. The most important objectives of PHBS are: (1) Increase stakeholders' strategic commitments and strategic 
alliances at the central, provincial, district, municipal, sub-district, village and kelurahan levels for the development of clean and healthy living behaviors (PHBS), (2) Increase alliances and partnerships with private / business world, (3) Increasing the participation of potential community / group organizations, (4) Development of PHBS guidance policy on house tana, educational institution, workplace, public place and health facility at all levels of government administration, (5) Strengthening the movement and participation of the community through PHBS in the household setting, educational institutions, workplaces, public places and health facilities, (6) Improving access to information and education to the community in the household setting, educational institutions, workplaces, public places and health facilities, and (7) Encourage the management capacity of PHBS guidance in the household setting, educational institutions, workplaces, public places and health facilities.

Improvement of PHBS is implemented through 5 orders, including the order of the household. There are 10 PHBS indicators of the household order, namely; (1) Relief delivery by health personnel, (2) Babies are given exclusive breastfeeding, (3) Having health care insurance, (4) The availability of clean water, (5) Availability of healthy latrines, (6) Conformity of floor area with number of occupants, (7) The floor of the house is not the ground floor, (8) No smoking in the home, (9) Perform physical activity every day, and (10) Eat fruits and vegetables daily.

Creed atmosphere is the creation of a conducive atmosphere to deceive the behavior of clean and healthy living. Clean and healthy life behavior can be created and developed if the environment supports. In this case the environment includes the physical environment, social, cultural, economic and political (Effendi, 2009).

Social status is divided into two (James M. Henslin, 2006: 93-94): (1) Default Status (ascribed Status), is not voluntary, does not ask and can not choose it. Inherit some binding status at birth, such as ethnic taste, gender and social class of parents and (2) Status Achievement (achieved status) otherwise, is voluntary. Status achieved or achieved as a result of efforts to become a student (education), a friend, a spouse, a priest, a priest, and another. Achieved status is the status a person acquires with deliberate efforts. This status is not obtained on the basis of heredity, but depends on the ability of individuals to achieve their goals. So this status is open to anyone. Example of every ordinary person to be a judge as long as it meets certain requirements, such as graduates of law faculty, has work experience in the field of law, and pass the examination as a judge. From the above understanding then to achieve status can also be seen from the level of education, income and employment.

According to LAPI ITB (2001) Coastal region becomes an area with natural resources that have significance in the present and future, which can be utilized for the purposes of settlement, tourism industry and others. The development of various interests that make the sea and coastal areas receive a heavy burden due to uncontrolled development, irregular, and without using the right technology. The environmental burden is in the form of environmental damage caused mainly by pollution, physical degradation of important habitats and over exploitation of natural resources. Of the many causes of damage to the marine and coastal environments, pollution can also decrease the aesthetic value of marine and coastal waters affected by pollution.

One of the causes of the high rate of environmental pollution of coastal waters is due to the assumption that coastal and marine waters are the disposal of waste from various human activities including industry. Therefore it is necessary to anticipate the efforts of marine pollution, either in the form of prevention, marine pollution control and environmental improvement.

Negative impacts caused by industrial, domestic and other activities on water resources in the form of declining water quality that may cause disturbance, damage and harm to all living things that depend on water resources. The main problem faced by the current water resources is related to the quantity that is no 
longer able to meet the increasing needs, the quality of water that is suitable for domestic purposes is also increasingly scarce obtained. Therefore, it is necessary to manage and protect the water resources carefully. Until now in Indonesia there has been Government Regulation No.20 of 1990 on the control of water pollution (Effendi.2000). River is one of the most important, both ecologically and economically. These waters are ecologically important because they sustain marine life in urban areas and are economically a source of income for fishermen and government in the form of tourism objects (P2O LIPI, 1998).

\section{Method}

This research with cross sectional approach because the independent variable and the dependent variable are taken at the same time simultaneously at that time. The subjects of the study were people living near or in the jorong of Nagari Sasak beach, which amounted to 242 families consisting of Jorong Pasa Lamo, Pondok, Pantai Indah Maligi, Suka Damai Maligi, Likes So Maligi and Padang Jaya Maligi taken from 9\% each jorong. The methods used to describe data include collection, organizing, and presenting data. The presentation of data can be explained in graphical form. This study uses regression analysis to see the relationship between $\mathrm{X}$ and $\mathrm{Y}$ variables. See the effect between the achieved status with clean and healthy life behavior in Sasak Pasaman Barat Coastal Coast. Taken directly in the form of data achieved status (level of education, occupation and income) is a variable $\mathrm{X}$ and 10 indicators PHBS household order is a variable $\mathrm{Y}$ by spreading a questionnaire to people living on the coast of sasak Pasaman Barat. The data obtained in the field is then processed using SPSS to obtain a relationship between achieved status with clean and healthy life behavior in Sasak Pasaman Barat Coastal Coast. After obtaining the results then mapped with a view from the coast then $100 \mathrm{~m}$ from the coastal area influence between achieved status with clean and healthy life behavior. Data analysis techniques using multiple linear regression test at $95 \%$ confidence level. Data processing by using SPSS to know the relationship between achieved status with clean and healthy life behavior. Data collection tool used in this research is a questionnaire. Questionnaires that have been collected are recording the score of each questionnaire. Forwarded by entering data using SPSS vesi 16 software, after data processed, then analyzed to determine the relationship between variables measured

\section{Result and Discussion}

This study used 242 respondents on average PHBS 2.3595 and standard deviation 0.56789 this indicates that the area in the research results have average behavior PHBS on healthy II, sepereti in table .

Tabel 1. Descriptive Statistics

\begin{tabular}{|l|r|r|r|}
\hline & \multicolumn{1}{|c|}{ Mean } & \multicolumn{1}{|c|}{ Std. Deviation } & \multicolumn{1}{c|}{ N } \\
\hline PHBS & 2.3595 & .56789 & 242 \\
Education & 1.7149 & .83325 & 242 \\
Work & .8719 & .39198 & 242 \\
\hline
\end{tabular}

Healthy Category II in this study illustrates from 10 indicators PHBS respondents only answered Yes 4-6 questions, with a score of 7-12, while Healthy III respondents can only answer Yes 7-9 questions, with a score of 13-18. So from the results obtained by the people living in Nagari Sasak, there are still people who have not implemented clean and healthy living behavior in their respective households. This application is highly dependent on the awareness and active role of the community in their respective neighborhoods. If the community has succeeded in realizing a clean and healthy lifestyle in the domestic order, so that it becomes a household that behaves in a clean and healthy life, then there are many benefits that can be felt in the present and future. 


\begin{tabular}{|l|l|r|r|r|r|}
\multicolumn{2}{|c|}{ Tabel 2. Correlations } \\
\hline \multirow{3}{*}{ Pearson Correlation } & \multicolumn{1}{|c|}{ PHBS } & Education & \multicolumn{1}{c|}{ Age } & \multicolumn{1}{c|}{ Work } \\
\cline { 2 - 7 } & PHBS & 1.000 & .147 & -.064 & -.053 \\
\cline { 2 - 7 } & Education & .147 & 1.000 & -.075 & -.087 \\
\cline { 2 - 7 } & Work & -.053 & -.087 & .020 & 1.000 \\
\hline \multirow{3}{*}{ Sig. (1-tailed) } & PHBS & .011 & .011 & .159 & .205 \\
\cline { 2 - 7 } & Education & .205 & .089 & .123 & .089 \\
\cline { 2 - 7 } & Work & 242 & 242 & 242 & 242 \\
\hline \multirow{3}{*}{$\mathrm{N}$} & PHBS & 242 & 242 & 242 & 242 \\
\cline { 2 - 7 } & Education & 242 & 242 & 242 & 242 \\
\cline { 2 - 6 } & Work & & & & \\
\hline
\end{tabular}

Table 2 shows the correlation matrix between PHBS and education and employment. Each variable shows a significant value smaller than 0.05 which means Ho is rejected. Thus, in this study there is a significant influence between each variable $\mathrm{X}$ on PHBS. From the table above shows that the large relationship between PHBS variable with education is 0.147 it shows a positive value. and the employment relationship with PHBS - 0.53 which also showed negative value. Positive value here means there is a positive relationship, the greater the educational variable the greater the PHBS value / the better the behavior PHBS, while the more negative the job variable the lower / bad behavior PHBS.

Tabel 3. Correlations

\begin{tabular}{|l|l|r|r|}
\hline & & \multicolumn{1}{|c|}{ PHBS } & \multicolumn{1}{|c|}{ Income } \\
\hline Pearson Correlation & PHBS & 1.000 & .095 \\
\cline { 2 - 4 } & Income & .095 & 1.000 \\
\hline \multirow{2}{*}{ Sig. (1-tailed) } & PHBS & .071 & .071 \\
\cline { 2 - 4 } & Income & .071 & 242 \\
\hline $\mathrm{N}$ & PHBS & 242 & 242 \\
\cline { 2 - 4 } & Income & 242 & \\
\hline
\end{tabular}

Table 3 shows the correlation matrix between PHBS and income. From the table above shows that the relationship between the variable PHBS with income is 0.095 this shows a positive value. Positive value here means there is a positive relationship, the greater the income variable the greater the value PHBS / the better the behavior PHBS.

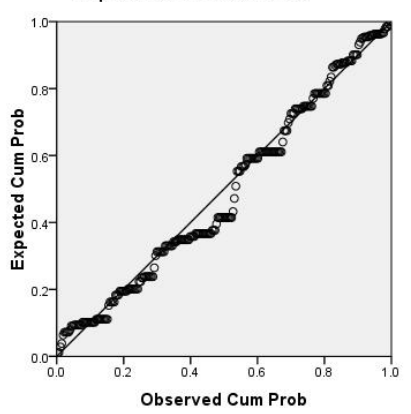


Clean and Healthy Living Behavior (PHBS) based on education level of Head of Family (KK) living in Nagari Sasak with elementary school education $50 \%$, junior high as $26 \%$, high school as much as $22 \%$ and non school $1 \%$. It shows that a very significant relationship between education and clean and healthy life behavior. The level of education is very influential on changes in attitude toward clean and healthy life behavior. Low levels of education affect the COW in digesting information to make choices in implementing the PHBS. The work in Nagari Sasak is the majority of the community are fishermen as much as $85 \%$, private $14 \%$ and civil servants as much as $1 \%$, fishing activities are very dependent on the weather. If the rainy season many of their days spent at home or to the shop, so that his income was disrupted or reduced. Wives mostly work as housewives, where they rely solely on income from fish catches. This study shows that the people in Nagari Sasak are in Healthy II and Healthy III, which means that 10 indicators of PHBS show that the overall indicator is not done by the community. From 6 Jorong examined 4 jorong categorized Healthy II and only 2 jorong that categorized Healthy III. This shows the characteristics of the people who work as troditional fishermen who mostly educated elementary school is assumed the low understanding of them terawang PHBS. According to Kusnadi (2003) the coastal community in general is a tradicional society who earn pas-pas. It is classified as poor by natural factors, dependent solely on seasonal catches. While nonalamiah limitations of fishing equipment technology. So that affects the family income.

\section{Conclusion}

Education Head of Family who live on the coast of Sasak Beach is Elementary School as much as $50 \%$. Public employment in general is about $85 \%$. There is an influence between occupation, education and peddling on PHBS. The higher the education, occupation and income hence the behavior of clean and healthy life is also increasing and the lower the education, occupation and income hence the behavior of clean and healthy life also decreasing.

\section{References}

Case.K. (2006). Economic Principles, Erlangga, Jakarta

Damar, A. (2003). 'Effects of Enrichment on Nutrient Dynamics Phytoplankton Dynamics and Productivity Indonesia Tropical Waters: A Comparation between Jakarta Bay, Lampung Bay and Semangka Bay' ', PHD Thesis, The Faculty of Mathematics and Nat, Sci, Christian Albrechts- Univ, Keil

Depkes RI. (2009). Guidance and Assessment of Clean and Healthy Living Behavior of Households Through TIM PKK Movers, Jakarta

Effendi. H. (2000). Study of Water Lecture: For Management of Water Resources and Environment ", Faculty of Fisheries and Marine Sciences, IPB

Elly, M.Setiadi, USman Kolip. (2011). Introduction to Sociology (Understanding Facts and Symptoms of Social Problems: Application Theory and Solutions). Jakarta: Kencana Prenada Media Group

Effendi Ferry. (2009). Community health nursing, publisher salemba medika

James. M. Henslin. (2006). Sociology with Earthed Approach. Jakarta: Erland.

Kusnadi. (2004). Polemik Poverty of Fishermen, Pustaka Yogyakarta Mandiri, Yogyakarta

LAPI ITB (Institute for Research and Industry Affiliation ITB). (2001). Development of Sea Pollution Database and Marine Pollution Control Planning, ITB, Bandung

MENKES. (2011). PHBS Guidance Guidance, Ministry of Health Regulation NUMBER: 2269 / MENKES / $\mathrm{PER} / \mathrm{XI} /$ 